JURNAL SENI MUSIK JSM (10)(1)

\title{
APPLICATION OF DEMONSTRATION AND DRILL METHODS FOR MUSIC ENSEMBLE PRACTICE IN JUNIOR HIGH SCHOOL STUDENT IN THE SOCIAL INTERACTION PERSPECTIVE
}

\section{Yuliana Sri Pangesti ${ }^{\bowtie}$}

Universitas Negeri Semarang

\section{Wadiyo}

Universitas Negeri Semarang

\section{Article Info}

Submitted : April, 2021

Revised : May, 2021

Accepted : May, 2021

\section{Keywords:}

Demostration Method; Drill; Musical Skill and Social Interaction

\section{Abstract}

The purpose of this study was to determine the application of demonstration and drill methods to practice music skills for junior high school students in the perspective of social interaction. This research used descriptive qualitative research methods using musicology, sociology and art education approaches. The data sources used were based on the results of interviews, observations, and documentation studies. The results of the study indicated that social interaction in learning involves teachers and students. The application of the drill method in learning music ensemble material is carried out by the teacher by presenting learning material to students through repeated exercises so that students can master the subject matter and are skilled in carrying out the exercises given as a form of effectiveness in using the drill method. In practicing musical ensemble skills, the drill method makes students more organized, thorough, and sharp in memory.

Social interaction in learning involves teachers and students. These interactions include ; 1) Interaction in learning, 2) teacher-student interaction, 3) student-student interaction. Interaction in learning occurs in the learning process.Teacher-student interaction occurs when students communicate with teachers. Interaction of students with students in groups of students when working on group assignments. 


\section{INTRODUCTIONS}

Education is one of the important needs for humans, both formal and non-formal education. Parents and the environment have a major role in developing education for children. In the family, parents function as individual builder so that they have ideal characters and traits to be able to live well in the community. Education is also defined as a process of changing attitudes and behavior of a person or group of people in an effort to mature humans through teaching and training.

Cultural Arts is one of the compulsory subjects in the junior high school education program (SMP), which refers to the curriculum unit (K13). In general, the purpose of cultural arts education is to provide students with an aesthetic experience. Hopefully, it can be a provision to face life in society, both in personal and in group. Through arts and culture education, students can develop the potential that exists within themselves. Based on Government Regulation Number 19 of 2005 concerning National Education Standards, every school or madrasa needs to pay attention to the interests, peculiarities of the region, schools, and students in developing the K13 Curriculum. In applying K13 to Cultural Arts lessons, schools may choose or apply four arts fields, namely visual arts, dance, music and drama. Demikian juga dengan metode atau model pembelajarannya, sekolah dapat menerapkan sesuai dengan karakteristik bidang seninya baik dalam apresiasi, kreasi maupun ekspresi (Wafa, 2016).

Art learning is learning that has unique properties and characteristics, through art learning, students are directed to develop themselves both in the cognitive, affective, and psychomotor domains. In Arts lesson, students can develop an attitude and capability in creating and appreciating the sense of art itself. One of students' activitiy that relates to creativity development is appreciating and developing their love to the music. The Music lesson should be taught easily and fun. Through Music lesson, the students are hoped to be more creative in practicing music, so that an appreciative and critical attitude are built. Music involves an ability to master vocal technique, playing music instruments, and appreciating musical works. Those several abilities can be said as a music skill training. That is why through a music learning, the students' talent and potential can be developed maximally. Of course, it can not be separated with the music teaching.
There are several learning components that can increase knowledge and skill of students are in learning lessons. One of them is the using of appropriate method that is used by teacher in delivering teaching material, either theory or practice. Several methods that can be applied are lecturing, discussion, question and answer, demonstration, drill, inquiry, etc. Generally, the selection of teaching method in music lesson should apply the learning of affective, innovative, creative, and fun. That is why, the teacher should be selective in choosing and using the methods in music learning.

SMP Negeri 1 (Junior High School 1) Simo is one of a school that applies Music lesson and practicing Ensemble music is one of the basic competency. The definition of Ensemble is a group of music with a simple arrangement of various music instruments, for example Pianica and Recorder that belong to melodic musical instruments, Cajon and Drum as ritmical music instrument and Guitar as harmonic musical instrument. The learning of Music Ensemble at class IX in SMP Negeri 1 Simo uses Pianica and Recorder as main instruments, and Guitar as additional instrument. The using of a right learning method in delivering musical ensemble material becomes an important consideration for teachers so that the teaching learning process can be effective and the students can understand material clearly. The learning process of Music in SMP Negeri 1 Simo for practicing ensemble music uses demonstration and drill methods. This method is choosen because it is efficient.

Demonstration method is a learning method that is applied by demonstrating things, events, rules, and sequences of activities directly and indirectly using a relevant teaching method with a presented material. This method is used so that students become more aware of the material described because they use visual aids and use visualization media that can help students understand better. (Bagaskara \& Salim, n.d.).

Learning the art of music in junior high school (SMP) can not be separated from the existence of social interaction in which the social interaction involves educators and students, with the presence of teachers and students, social interaction requirements have been met, namely contact and communication. Because it can be said a social interaction when the social interaction occurs if there are two conditions that are passed, namely the existence of social contact and communication. 
In this study, the research subjects were grade IX students at SMP Negeri 1 Simo. Based on the preliminary results of the researchers' observations, it was shown that the IX grade students at SMP Negeri 1 Simo were students who liked the art of music. This is proven by the responses of students who dared to express and be creative in several project assignments related to musical skills training. The interest of students in the art of music is because the teacher can apply learning methods appropriately. Learning the art of music in general must use methods. The selection of teaching methods applied by teachers in learning the art of music at SMP Negeri 1 Simo is the demonstration and drill method. This method emphasizes the skills of students both in vocal techniques and using musical instruments.

\section{METHODS}

This research uses descriptive qualitative research methods using musicology, sociology and art education approaches. The musicological approach is carried out by involving the theory of harmony science, the data taken are sourced from secondary data audio, video, sheet music, literature, and documents. The data sources used are based on the results of interviews, observations, and documentation studies. Data analysis techniques used by researchers are data reduction techniques, data presentation and conclusion drawing (Miles. M, B., \& Huberman, 1994). The data validity technique used is source triangulation and technical triangulation.

\section{RESULTS AND DISCUSSION}

\section{Social Interaction in the Ensemble Practice}

Musical ensemble learning by applying demonstration and drill methods is considered effective because it is supported by a learning system that takes place face-to-face or offline where teachers and students meet face-to-face or face to face. By meeting teachers and students directly, there is a social interaction that involves contact and communication. It can be said to be a social interaction if the social interaction occurs through two conditions, namely the existence of social contact and communication.

Learning ensemble music is closely related to social interactions involving teachers and students. With contact and communication during the learning process, the requirements of social interaction are met, for example when the teacher is teaching in the classroom, giving ensemble musical material on fingering techniques on a recorder, demonstrating how the finger position is used when playing a musical instrument. the recorder then the students pay attention to the teacher who is giving an example. In this stage the teacher has made a contact with students through giving examples of exercise material to students, and students communicate by looking at and paying attention to the teacher then students ask. If they encounter difficulties, from this emerges a network of reciprocal relationships where one speaks, and the other listens, one asks, the other answers, one gives orders, the other obeys.

\section{Social Interaction}

Social interaction comes from the Latin: Con or Cum which means together, and tango means giving touch, so the literal meaning is touching together. Social interaction is a process in which individuals with individuals, individuals with groups, or groups with groups relate to one another (Suyanto, 2014). Social interaction is a social intensity that regulates how people behave and interact with one another. Social interaction is the basis for creating patterned social relationships called social structures. Social interaction can also be seen as a social process in which it orients itself to others and acts in response to what others say and do (Nasdian, 2015).

Interaction is seen as something important to be maintained, can change behavior, meaning, and language. In other words, through interaction, a person can quickly and easily find out about something he wants. Learning in schools is a network of reciprocal relationships where one can speak, and the other can hear, one asks, the other answers, one gives orders, the other obeys. It always seems that people influence each other. Max Weber emphasizes the fact that interaction lies in directing behavior to others, there must be a reciprocal orientation between the parties concerned (Fahri \& Qusyairi, 2019). Based on this, it can be concluded that social interaction is also called a social process in which there is a reciprocal relationship between two or more people, and each person involved plays an active role. In interaction, there is more than just a relationship between the parties involved, but also mutual influence.

A social interaction can occur if there are two conditions that are passed, they are the existence of social contact and communication. Social contact can literally be understood as touching each other. Touch does not have to be understood physically so that a touch can occur, for example through various media or through technological means. Today's technological developments allow 
people to communicate, for example via telephone, radio, television, mail, internet, and so on, which obviously does not require a physical relationship. In ansocial life, each individual with other individuals must hold communication which is the main tool for fellow individuals to get to know each other and work together as well as make physical and non-physical contacts by learning directly or indirectly. The occurrence of contact does not mean that there has been communication, therefore communication can arise when an individual gives an interpretation of the other behavior. In that interpretation, then someone manifests behavior that it is a reaction to the feelings that other people want to convey. School is one of the important social contexts for individual development, however, the development of students is also strongly influenced by other social contexts, it is relationships with friends. Social interaction can be divided into several forms. The form of social interaction according to Soekanto is that social interaction is categorized into a form of cooperation competition, accomodation, and conflict (Soekanto, 2005).

In the interaction of the implementation of learning, there are many factors that influence the success and failure of changes that occur in students for improvement. According to Mulyasa (2005), this is because of internal factor that comes from individual or external factor that comes from environment. Individual factors include maturity, intelligence, training, motivation and personal factors. While external factors include family or community environment and school environment including teachers and educational institutions, tools needed and used in teaching and social motivation.

\section{Social Interaction in Learning}

Learning arts and culture, especially music, for ensemble music skills training material is closely related to social interactions involving teachers and students. With contact and communication when the learning process is in progress, the requirements for social interaction have been met, it is the existence of contact and communication. The learning of cultural arts especially music in ensemble music skills training material takes place with two-way interaction, they are between teachers and students, and students and students. If each student or group experiences a problem related to the ensemble material, students can ask the problem directly to the teacher, but if in practice the problem has not been resolved, students have practiced in groups, then students can ask friends between groups.
When asking through friends between groups but the problem has not been solved, students can ask the teacher.

In one group, there is a division based on the musical instrument played, some play guitar, recorder, pianika. When students playing recorders have difficulty finding the position of the $\mathrm{E}^{2}$ note, there are other friends who can already find the position and play the $\mathrm{E}^{2}$ chord, students who have difficulty can ask those who can, and if the tone shot is still not right, then the student can communicate with the teacher, this kind of interaction occurs in the practice of ensemble music skills at SMP Negeri 1 Simo.

\section{Interaction Between Teacher and Student}

While teaching, the teacher gives ensemble music material regarding fingering techniques on recorder musical instruments, $\mathrm{He} / \mathrm{She}$ demonstrates how the position of the fingers used when playing the recorder instrument is then the students pay attention to the teacher who is giving an example. In this stage the teacher has made contact with students through giving examples of exercise material to students, and students communicate by seeing and paying attention to the teacher and then students asking if they encounter difficulties. From this emerges a network of reciprocal relationships where one speaks, and the other listens, one asks, the other answers, one gives orders, the other obeys.

Learning tutorial video media provided by teachers to students creates a reciprocal network between teachers and students, the network is a form of social interaction that takes place during the learning process, for example: when the teacher gives examples of learning materials through video tutorials to students, students watch and listen, then if students confuse, students can ask the teacher. Here comes contact and communication, the teacher teaches and students ask or pay attention, then there has been an interaction process between teacher and students. In the implementation of ensemble music learning, the teacher asks students to form groups, if each student or group experiences a problem related to the ensemble material, students can ask the teacher.

\section{Interaction among Students}

The process of social interaction does not only occur between teachers and students, but also between students and students, for example; through learning video media, the teacher gives assignments or exercises to students to make 
ensemble musical instrument video games. The teacher asks students to form groups. Here comes a network of relationships between students and students, namely the process of social interaction between one group and another. Students can ask friends or other students if they experience problems in the process of making a video of coursework assignments. Students with each other also interact to communicate with each other the exercise assignments given by the teacher. However, if in practice the problem has not been resolved and students have practiced in groups, then students can ask friends between groups, when asking through friends between groups but the problem has not been solved, students can ask the teacher.

In one group, there is a division based on the musical instrument played, some play guitar, recorder, pianika. When students playing recorders have difficulty finding the position of the $\mathrm{E}^{2}$ note, there are other friends who can already find the position and play the $\mathrm{E}^{2}$ chord, students who have difficulty can ask those who can, and if the tone shot is still not right, then the student can communicate with the teacher, this kind of interaction occurs in the practice of ensemble music skills at SMP Negeri 1 Simo.

Students' interest in playing ensemble music is very high, especially if the teacher provides material for popular songs or songs that are popular at the time, students will be more interested and enthusiastic to learn. In ensemble music, the teacher also instills character values, through ensemble music learning, students are directed to learn an instrument which requires discipline, for example: when students learn to play a recorder musical instrument. Students need discipline, seriousness and sincerity. Without discipline and earnest students will have difficulty when learning it. When students are able to discipline themselves, automatically the character of students to be disciplined in any field will also be disciplined. The building of character values in ensemble music playing is automatically embedded in students through the training process carried out by students from discipline, a sense of responsibility, cooperation between friends with one another in a group.

Ensemble Music lesson in SMP Negeri 1 Simo has a general instructional goal, it is that students are expected to have one skill or experience in music which can later be developed independently as a life skill in which with these skills students can get rewards, besides that students also get musical experience which students can later use if they want to continue to a higher level in the field of music.

\section{CONCLUSION}

Based on the results and discussion regarding the application of the demonstration and drill method for practicing music skills for junior high school students in the perspective of social interaction, that the implementation of the demonstration method is carried out by the teacher by practicing directly on the students then students follow and imitate carefully. Furthermore, the teacher provides explanatory material to make it easier for students to practice it. Through the demonstration method, learning takes place effectively. There are three songs to be practiced, such as Suwe Ora Jamu, Ibu Kita Kartini, Kasih Ibu. The demonstration method makes the learning process more interesting, because students not only listen, but also see the teacher demonstrating directly what is being learned.

The application of the drill method in learning the art of music in ensemble material is carried out by the teacher by presenting learning material to students through repeated exercises so that students can master the subject matter and are skilled in carrying out the exercises provided as a form of effectiveness in using the drill method. In the practice of ensemble music skills, the drill method makes students more organized, thorough, and sharp in memory.

Social interaction in learning involves teachers and students. These interactions include; 1) Interaction in learning, 2) teacher-student interaction, 3) student-student interaction.

Interaction in learning occurs in the learning process. teacher-student interaction occurs when students communicate with teachers. Interaction of students with students in groups of students When working on group assignments.

\section{REFERENCES}

Bagaskara, A., \& Salim, A. (n.d.). Metode Pengajaran Drill Dan Demonstrasi Di Kelas Musik Band SLBN Yogyakarta.

Nasdian, F. T. (2015). Sosiologi Umum. Jakarta: Buku Obor.

Peraturan Pemerintah Nomor 19 Tahun 2005 tentang Standar Nasional Pendidikan 
Bagaskara, A., \& Salim, A. (n.d.). Metode Pengajaran Drill Dan Demonstrasi I Di Kelas Musik Band SLBN 2 Yogyakarta.

E.Mulyasa. (2005). Kurikulum Berbasis Kompetensi: Konsep, Karakteristik, dan Implementasi. Remaja Rosdakarya.

Fahri, L. M., \& Qusyairi, L. (2019). Interaksi Sosial dalam Proses Pembelajaran. PALAPA, 7(1), 149-166. https://doi.org/https://doi.org/10.36088/ palapa.v7i1.194

Miles. M, B., \& Huberman, A. M. (1994).
Qualitative Data Analysis (2nd ed.) (2nd ed.). Sage Publications.

Soekanto, S. (2005). Sosiologi Suatu Pengantar. PT RajaGrafindo Persada.

Wafa, M. U. (2016). Implementasi Konsep Ekspresi dan Kreasi Dalam Pembelajaran Seni Musik di SMP Karangturi Kota Semarang. Jurnal Seni Musik, 5(1). https://doi.org/https://doi.org/10.15294/j sm.v5i1.18400 